\title{
THE LENDER OF LAST RESORT: A HISTORICAL PERSPECTIVE
}

\author{
Thomas M. Humphrey and Robert E. Keleher
}

\section{Introduction}

The current international debt situation has led some analysts to suggest the possibility of a scenario whereby international debt defaults quickly lead to severe strains on domestic commercial banks. In this context, monetary and central bank policy become especially important, and references are often made to the central bank's function as lender of last resort (LLR). In considering stopgap versus permanent solutions to financial crises, the role of the lender of last resort assumes special pertinence.

Although often mentioned, few thorough assessments of the domestic LLR function exist. Moreover, the analytical foundations or theoretical framework underlying the LLR function are rarely if ever spelled out. Discussions of this central bank role are often premised on differing definitions or understandings of the function. As a result, semantic problems often cloud such discussions. Then too, clarifications of the LLR function under alternative monetary and exchange rate regimes have never been made. Consequently, analyses of the concept are frequently ambiguous. Because of this lack of clarity, analyses of this role often leave important issues unresolved. For example, is the LLR essentially a banking or a monetary function? Is the function microeconomic or macroeconomic in nature; that is, does LLR responsibility pertain to individual banks or to the market as a whole? Are the monetary control and LLR functions of a central bank irreconcilable? Does the LLR function differ under alternative

Cato Journal, Vol. 4, No.1 (Sprting/Summer 1984). Copyright (c) Cato Institute. All rights reserved.

Thomas M. Humphrey is a Research Officer and Economist at the Federal Reserve Bank of Richmond. Robert E. Keleher is a Research Officer and Senior Economist at the Federal Reserve Bank of Atlanta. The views expressed herein are solely those of the authors and do not necessarily represent the views of thoir respective banks or of the Federal Reserve System. 


\section{Cato Journal}

monetary regimes? Is current Federal Reserve policy in accord with the original conceptions of this function? Can the role be carried out via open market operations or must the discount window always be used? This lack of clarity of the LLR function is evident in discussions of the domestic LLR. But the confusion becomes especially apparent in analyses of international financial crises and particularly when a role for an international LLR is proposed.

In an effort to dispel this confusion, it is useful to reassess this important central bank function. The purpose of this paper is to examine both the domestic and possible international roles of an LLR. We begin with a discussion of the function of an LLR. Next, a brief outline of the role of an LLR under various monetary regimes is presented. We then consider the historical development of the concept of a domestic LLR. Special attention is given to the work of Henry Thornton, the Banking School, and Walter Bagehot. A discussion of the possible role for an international LLR and some conclusions complete the paper.

\section{The Function of the Lender of Last Resort}

The call for an LLR arises because of two important institutional characteristics of contemporary monetary systems, fractional reserve banking and governmental monopoly of legal tender issuance. 'The monopoly of legal tender issuance ensures that the central bank is the ultimate provider of currency and thereby the guarantor of depositto-currency convertibility. Once banks believed they could always obtain currency in a crisis from such a monopoly issuer, they reduced their holdings of reserves and began to hold assets they believed could be easily transformed into reserves (or legal tender). This contributed to a centralization of reserves under the custody of the monopoly issuer, the "central" reserve bank. The discussion of the LLR in this paper is premised on these given institutional arrangements. Thus, while we believe strongly in free competitive markets for all goods (perhaps including money) and are sympathetic in

\footnotetext{
'With 100 percent reserve requirements, an LLli would not be necessary. Moreover, monetary systems characterized by multiple issuers of transactions media could be proposed and indeed have existed without any apparent need for an LLR. The monopoly of legal tender issuance applicd to the Bank of England by 1833 . Even for several decades before that date, the Bank of England's notes were de facto legal tender. (White 1981a, 1981b; Smith 1936). In addition, it should be noted that FDIC insurance does not nullify the need for an I.LR. First, current FDIC pricing schomos aro likely to be changed in the near future. Second, an LLR is essential (ultimately) to back up FDIC insurance. Third, the United States has one of the very few government-supported deposit insurance schemes.
} 
principle to the arguments of free-money advocates and their case against the LLR, we nevertheless intend to examine the function of existing LLRs under existing institutional arrangements. ${ }^{2}$ We hope that such an examination will provide a better understanding of the role existing LLRs may play in banking crises and help us evaluate various proposals for an international LLR.

Given existing institutional arrangements, monetary systems are vulnerable to sharp increases in the demand for the safest and most readily acceptable form of money, namely currency (or, under a metallic standard, gold). Such sharp increases in demand for currency or gold can bring about a widespread call-in of loans and a dramatic fall (or collapse) of asset prices. Historically, such increases in demand were often associated with runs on banks and a collapse of loans and deposits. Consequently, a role of the LLR is as a backstop or guarantor to prevent a panic-induced collapse of a fractional-reserve banking system. Since such banking systems connect movements in credit (chiefly bank loans and investments) to movements in money, the primary function of the LLR is to prevent credit crises from becoming monetary crises; that is, to prevent credit/debt contraction from producing monetary contraction.

Thus, while the LLR should prevent systemwide runs on banks, large-scale loan call-ins, and collapses of asset prices, loans, and credit, its ultimate purpose is to prevent collapses of money-to promote monetary stability. The LLR has both the power and the duty to achieve this goal. For, whereas government has little or no reason to intervene in the lending decisions of financial intermediaries, the granting of monopoly powers to a single note issuer carries certain governmental responsibilities with it. Specifically, since certain negative extemalities (such as disruptions to real activity, to the payments system, and to financial intermediation) are commonly associated with monetary instability, a governmental role for preventing such negative externalities and consequently providing for monetary stability is implied by the creation of monopoly note issuance.

The monetary stabilization responsibility of the LLR relates to marketwide (macroeconomic) effects and not to individual bank (microeconomic) effects. The LLR function, then, pertains to the

${ }^{2}$ For an excellent discussion of the arguments relating to the existence of LLRs, see White (1981a, 1981b) and Smith (1936). While sympathetic to these arguments, we follow arguments of the Public Choice School and thereby remain skeptical that the objectives of frec-money advocates can be realized in the political world in which we live. That is, we doubt that many governmonts and bureaucracies will be willing to relinquish the power inherent in governmental central banking. See Mundell (1983a, pp. $30-32$ ). 


\section{Cato JournaL}

responsibility of guaranteeing the liquidity of the entire economy but not necessarily of particular institutions, Moreover, the LLR role is not to prevent all shocks to the fnancial system, but rather to minimize the secondary repercussions of those shocks. Accordingly, the LLR is charged with averting contagion, spillover, or domino effects which may adversely affect the stability of the entire monetary system. In essence, the purpose of the LLR is to maintain sufficient confidence in the financial system so that there will be no need to provide last-resort liquidity.

One indirect implication of this liquidity-provision responsibility is worth mentioning. The effective exercise of this liquidity responsibility will prevent a drastic and widespread call-in of loans as well as a dramatic fall (or collapse) of asset prices. Thus, in providing this function, the LLR indirectly ensures that banks needing to sell liquid assets will not have to do so at large losses that might otherwise bring about insolvency and its adverse effects.

These objectives should be fully acknowledged and widely announced to the public before any crisis occurs. Credible assurance of this kind is necessary to reduce the uncertainty about the central bank's willingness to act. This, in turn, promotes confidence and generates stabilizing expectations that help to avert future panics. To minimize so-called "moral-hazard" problems, such an advance announcement should indicate that assistance will not be available to unsound banks but only "to the market."

The LLR function, therefore, is a short-run stabilization function which need not necessarily conflict with longer-run central bank objectives. Such longer-run objectives may differ somewhat under alternative monetary regimes. Accordingly, the precise operational mechanism or tools needed to provide LLR services may differ under alternative regimes. ${ }^{3}$

\section{Lender-of-Last-Resort Services Under Alternative Monetary Regimes}

Historically, explanations of the LLR function have developed out of the peculiarities of time and place. Many authors who initially explained the LLR function did so from the perspective of a small open economy often operating under fixed exchange rates; that is, under an international commodity (or gold) standard. These economists had a tendency to generalize from their own knowledge or

\footnotetext{
${ }^{3}$ For a brief summary of alternative monetary regimes and their implications, see
} Humphrey and Keleher (1982). 
experience of a particular time and place to situations under which the experience may not be relevant (Mundell $1983 \mathrm{~b}, \mathrm{p} .286$ ). Accordingly, the influence of fixed exchange rates in an open economy clearly dominated many of the early explanations of the LLR.

In the case of a small open economy under fixed exchange rates (or a gold standard), for example, the longer-run objective of a domestic central bank is not to directly control the total money supply but rather to maintain (fixed-rate) convertibility of currency into international reserves (or gold). If this convertibility is maintained, the growth of the money supply is tied to the (presumably stable) growth of world international reserves (or gold stock). To maintain the stock of international reserves, the central bank has to ensure that the domestic paper note component of the money supply does not grow so fast as to force an efflux of international reserves through the balance of payments, thereby endangering convertibility. Thus, control over the domestic note component of the money stock is a necessary condition for the long-run maintenance of convertibility. In short, central bank responsibility under this regime involves keeping the domestic credit component of the money stock on a target path consistent with protection of the specie reserve and hence with longrun maintenance of convertibility. Also, under this regime, widespread bank runs and a collapse of the fractional reserve banking system could trigger large internal drains of specie that would threaten to exhaust the gold reserve and endanger convertibility. The function of the LLR under these circumstances, therefore, is to prevent such a collapse and thereby to complement and promote the goal of maintaining convertibility. Thus, the role of the LLR is to prevent credit crises and the associated runs on specie reserves from adversely affecting the longer-run monetary objectives of the central bank.

Crisis situations involving the LLR frequently followed excessive credit expansions. Such credit expansions often were large and prolonged enough to produce outflows of specie and to foster doubts about the ability of commercial banks to redeem their paper in gold. More precisely, when an overexpansion of loans and thereby of bankcreated money occurred in a small open economy, an external drain of international reserves (or gold) normally followed as a necessary element of the balance-of-payments adjustment mechanism. Under such circumstances, restrictive monetary policy was deemed appropriate to stem the reserve (or gold) outflow and thereby maintain convertibility. However, because some banks typically had been overzealous or imprudent in their lending, the quality of their loan portfolios sharply deteriorated in the adjustment phase of the credit cycle. Depositors and note holders, fearing for the safety of their 
deposits and notes, withdrew deposits (or requested conversion of deposits and notes into currency or gold) and thereby created an internal drain. Appropriate policy action under an internal drain was expansionary in order to accommodate demands for currency, to promote confidence, and thereby to stem the possibility of widespread bank runs, the collapse of the fractional reserve banking system, sharp contractions of the money supply, and the suspension of convertibility.

The policy prescription for simultaneously meeting external and internal drains was to "lend freely at a high (penalty) rate." A high bank rate attracted foreign capital and hence stemmed the external drain. At the same time, a high bank rate rationed the scarce reserves among eager borrowers and ensured that central bank lending was indeed last-resort lending by providing an incentive for banks to exhaust market sources of liquidity before coming to the central bank. ${ }^{4}$ Yet, lending freely ensured that credit remained available, so that a sharp fall in bank asset prices would not have to occur (since a market for these assets was provided). This helped to promote confidence in the banking system and thereby prevented secondary runs or contagion. Since the discount rate was the principal and convenient policy tool under a regime of fixed exchange rates, lastresort liquidity was normally provided via the discount window. The provision of such liquidity, therefore, became synonymous with discount-window lending by the "lender" of last resort. In short, the LLR function complemented, rather than conflicted with, the central bank's monetary objectives of maintaining a convertible currency and stable growth of the domestic note issue.

In the cases of a small open economy under flexible exchange rates and a closed economy, direct monetary control becomes a viable target of monetary policy. That is, when the convertibility requirement no longer exists to influence policy, monetary and price-level stability may become a direct objective of central bank policy. Given fractional-reserve banking and governmental monopoly of legal tender issuance, however, economies under both of these regimes still remain vulnerable to bank runs and the collapse of fractional-reserve banking, and thereby to sharp contractions of the money supply. Again, the function of the LLR under these regimes is to prevent

${ }^{4}$ There was an additional rationale for the high bank rate. Specifically, it ensured that the domestic-credit component of the money stock would be kept on a noninflationary path. For when bankers are forced to borrow money from the LLR at a penalty rate, they will be eager to pay off those loans when the panic expires. The resulting loan repayment will extinguish the emergency increase in the money stock, bringing that stock back on path. 
credit crises and instability from creating monetary crises and contraction; that is, to prevent banking collapses from affecting the money supply.

Under both the closed-economy and Hexible-exchange-rate regimes, the pursuit of monetary stability automatically results in the provision of last-resort liquidity. Achieving monetary stability necessarily means that sharp increases in the demand for coin and currency be accommodated in order to prevent sharp contractions in the money stock. Stability in monetary growth will also tend to minimize the volatility of credit and therefore lessen the likelihood both of sharp collapses in the prices of bank assets and of widespread bank runs. Such policy objectives typically are most conveniently provided through open market operations. Although many economists still do not associate open market purchases with the LLR function, such purchases are a particularly efficient way of providing liquidity to the market. They have the advantage of speed as well as that of regulating the total amount of reserves, but not their allocation among particular users.

LLR provision of liquidity during a crisis via open market operations does not conflict with longer-run monetary control. Specifically, prompt and vigorous LLR action will stop any panic within a very short time, long before the supply of high-powered money strays very far off its stable long-run path. Also, to the extent that the emergency expansion of high-powered money merely offsets panicinduced rises in currency and reserve ratios, the money stock will remain largely unchanged. As a result, any deviation of the money supply from its long-run target path will be small both in magnitude and duration. Thus, the LLR function is essentially a very short-run function of a central bank which is only activated during temporary periods of emergency. The stabilization of money and prices is a continuous and longer-run function. Consequently, the functions are not in conflict. Indeed, since the LLR function works to prevent sudden decreases (shocks) of the money stock, it is fully consistent with a "gradualist" approach to monetary control. The monetary control and LLR functions, therefore, are complementary rather than conflicting functions.

In sum, the lender of last resort has the same objective under different regimes: to prevent short-run credit instabilities from affecting longer-run monetary objectives. The short-run LLR function does not conflict with, but rather complements, the longer-run monetary objectives.

Lucid explanations of the above-described central bank LI.R function were presented by several early monetary theorists. The concept 
of the LLR was developed and refined during the course of important monetary debates of the 19th century and often after a monetary crisis. Indeed, as Charles Rist (1966, p. 380) emphasized: "Central banks of issue, and consequently their functions and operations, really developed in the course of the nineteenth century." These earlier monetary writers spelled out the LLR function both more clearly and more consistently than many modern authors. For this reason, a thorough and clear understanding of this function and its important implications can best be obtained by reviewing its historical development, and by recognizing the different monetary regimes under which these important authors developed their interpretations.

\section{Henry Thornton's Early Presentation of the Theory of a Lender of Last Resort}

The term "lender of last resort" owes its origin to Sir Francis Baring, who in his Observations on the Establishment of the Bank of England (1797) referred to the Bank as "the dernier resort" from which all banks could obtain liquidity in times of crisis. But the concept itself received its first-and in many respects still its most rigorous, complete, and systematic-treatment in the hands of Henry Thornton. It was Thornton who, in his testimony before Parliament, in his speeches on the Bullion Report, and in his classic An Enquiry Into the Nature and Effects of the Paper Credit of Great Britain (1802), identified the Bank of England's distinguishing characteristics as an LLR. It was he who also specified the LLR's primary function, who distinguished between the microeconomic versus macroeconomic and shock-preventing versus shock-absorbing aspects of this function, and who analyzed its relationship with the monetary control function of the central bank. Finally, it was he who first enunciated the so-called "moral hazard" problem confronting the LLR.

Thornton identified three distinguishing characteristics of the LLR. First was its unique position as the ultimate source of liquidity for the financial system. The LLR, he pointed out, maintained and created a strategic stock of high-powered money that could be used to satisfy demands for liquidity at critical times. More precisely, it held the central gold reserve from which all banks could draw. Equally important, it supplied the other (non-gold) component of the monetary base in the form of its own notes-notes which, by virtue of their unquestioned soundness and universal acceptability, were considered the equivalent of gold and therefore constituted de facto legal tender. The Bank's effective monopolistic power to issue these notes 
gave it sole control over an inexhaustible source of domestic legal tender-the first requisite of an LLR.

The second distinguishing characteristic of the LLR identified by Thornton was its special responsibilities as custodian of the central gold reserve. Not only must it hold sufficient reserves to inspire full confidence in their ready availability in times of stress, but it must also rely on its own resources (since as the last resort, it can turn to no other source) to protect the reserve from gold-depleting specie drains. Specifically, it must stand ready to freely issue its own paper to stem the panics that bring about internal specie drains. And, while relying on its control over the issue of monetary notes to prevent external drains caused by persistent inflationary over-issue of paper, it must hold so large a reserve as to be able to withstand those temporary and self-reversing external drains originating in real shocks to the balance of payments. Should the Bank nevertheless find its reserve exhausted and the gold in circulation depleted by an extraordinary succession of such shocks (Thornton mentions three successive crop failures), it must take steps to ensure that the eventual return flow of gold is not delayed by domestic monetary contractions that depress aggregate production and thus reduce output available for export. For, according to Thornton (1939, p. 118), given downward inflexibility of wages and prices in the face of money-induced declines in aggregate demand,

the manufacturer, on account of the unusual scarcity of money, may even ... be absolutely compelled by necessity to slacken, if not suspend, his operations. 'To inflict such a pressure on the mercantile world as necessarily causes an intermission of manufacturing labour, is obviously not the way to increase that exportable produce, by the excess of which, above the imported articles, gold is to be brought into the country.

In short, the central bank must ensure that temporary external drains originating in a succession of transitory real disturbances are not prolonged by secondary monetary shocks. To do this, it must sterilize or neutralize those gold drains with temporary increases in its own note issue. In so doing, it maintains the base of high-powered money and prevents sharp contractions in the money stock, contractions which, by depressing manufacturing activity and thus reducing output available for export, would prolong the deficit in the balance of trade and hinder the return flow of gold. By judicious expansion of its own paper, the Bank of England arrests and reverses these specie drains that imperil its gold reserve.

The third characteristic of the LLR, according to Thornton, was that it was not just like any other bank; it had public responsibilities. 


\section{Cato JOUknaL}

Unlike an ordinary commercial banker, whose responsibilities extend only to his stockholders, an LLR's responsibility, Thornton asserted, extends to the entire economy. Specifically, the LLR's duties include preserving the aggregate quantity and hence purchasing power of the circulating medium during bank runs and panics, and assisting the entire financial system in times of crisis. This responsibility, he argued, dictates that the LLR behave in a way precisely the opposite of that of a commercial banker in times of distress, expanding its note issue and loans at the very time the banker is contracting his. For whereas the individual banker can justify his loan and note contraction on the grounds that it will enhance his own liquidity and safety while not materially worsening that of the whole economy, the LLR can make no such assumption. On the contrary, the LLR must assume that, because of its influence over the total money supply, any contractionary policy on its part would adversely affect the economy. Consequently, the LLR must expand its note issue and loans at a time when the prudent commercial banker is contracting his. To be in a position to do this, the LLR, Thornton noted, must hold much larger cash reserves than the ordinary bank.

Having outlined the distinctive features of the LLR, Thornton next expounded on many issues relating to central banking, but four in particular are especially relevant to the LLR. The first concerns a possible conflict between the central bank's responsibility as controller of that part of the monetary stock which consists of domestic notes and its function as lender of last resort. To the extent that the central bank bears the responsibility for providing a stable framework of the domestic note component of monetary growth, it must exercise a moderate and continued restraint on the rate of expansion of its own note issue. It must exercise such restraint either to protect its international reserves from displacement by excess paper so that it can maintain the convertibility of its currency under fixed exchange rates or to prevent domestic inflation under floating exchange rates. But coping with unusual liquidity strains or panics through exercise of the LLR function calls for abandonment of this restraint and relinquishing control over the rate of expansion of the note component of the monetary base. Hence, some banking specialists have noted an apparent conflict between these two central banking objectives.

Thornton, however, saw no inconsistency between a policy of stable monetary growth and the actions required to deal with liquidity crises. In the following passage, which Joseph Schumpeter has called the "Magna Carta of central banking," Thornton distinguishes between the long-run target growth path of the note component of the monetary base and temporary emergency deviations from the 
path. The proper policy of the Bank of England, Thornton (1939, p. 259) said, is

[T]o limit the total amount of paper issued, and to resort for this purpose, whenever the temptation to borrow is strong, to some effectual principle of restriction; in no case, however, materially to diminsh the sum in circulation, but to let it vibrate only within certain limits; to afford a slow and cautious extension of it, as the general trade of the kingdom enlarges itself; to allow of some special, though temporary, increase in the event of any extraordinary alarm or difficulty, as the best means of preventing a great demand at home for guineas; ${ }^{|5|}$ and to lean to the side of diminution, in the case of gold going abroad, and of the general exchanges continuing long unfavourable; this seems to be the true policy of the directors of an institution circumstanced like that of the Bank of England. To suffer either the solicitations of merchants, or the wishes of government, to determine the measure of the bank issues, is unquestionably to adopt a very false principle of conduct.

Thus, to Thornton, the main responsibility of the central bank was to regulate the domestic paper component of the money stock so that it expands at a steady noninflationary pace roughly comparable to the long-term growth rate of output. The bank must also counter those specie drains that periodically threatened to deplete its gold reserve and force suspension of convertibility. As previously mentioned, these drains were of two types: external (or foreign), composed of exports of gold to cover an adverse balance of payments in the country's international accounts and, internal, consisting of panicinduced increases in the quantity of gold held by domestic residents. Temporary (self-reversing) external drains arising from transitory real shocks to the balance of payments can normally be met from the large buffer stock of gold reserves held precisely for that purpose, the temporary runoff of gold being offset by a reverse flow later on. But an extraordinary succession of such drains, if sufficient to exhaust the metallic reserve and deplete the gold in circulation, may require expansionary policy. Such policy, Thornton argued, would neutralize (sterilize) the gold outflow, prevent needless monetary contraction and the resulting disruption of the export industries ("those sources of our returning wealth"), and thereby contribute to the prompt correction of the trade deficit and the speedy return of gold. By contrast, persistent external drains arising from inflationary over-issue of paper call for restrictive policy. Either by reducing inflated British prices relative to foreign prices or by creating an excess demand for money

${ }^{5}$ Thornton is here referring to the public's demand for gold coin, the guinea being the name of a standard gold coin in use in England at the time. 
which domestic residents attempt to satisfy by selling more goods and buying less, such restrictive policy spurs exports, checks imports, eliminates the trade-balance deficit, and halts the outflow of gold. Clearly monetary contraction, he thought, is the correct remedy for persistent external drains.

In the case of a panic and internal drain, however, the Bank should be prepared temporarily to expand sharply both its note issue and its loans to satisfy the public's demand for high-powered money. This means that the Bank must step off its path of stable note growth to prevent the money stock from shrinking. Indeed, Thornton argued that emergency expansions of Bank of England notes were required to keep the stock of paper money (Bank notes plus notes issued by commercial banks) on path in the face of panic-induced rises in currency and reserve ratios. There need be no conflict between the functions of monetary control and lender of last resort, however, since the first refers to the long run and the second to temporary periods of emergency that may last for only a few days. Although he had no penalty rate mechanism to extinguish the emergency increase of base money and return it to path once the panic was over, he did argue that if the central bank, in its role as an LLR, responds promptly and vigorously to the threat of a liquidity crisis, the panic will be averted quickly. Indeed, Thornton held that the mere expectation of such a response may be sufficient to stop the panic before additional notes are issued. Thus, the deviation of the money stock from its long-run target path will be small, both in magnitude and duration.

The second issue considered by Thornton concerns the extent of the lender of last resort's responsibility to individual banks as opposed to the banking system as a whole. Suppose these individual banks are unsound. Must the LLR act to prevent their failure; that is, are bailout operations necessary to preserve the stability of the payments mechanism? According to Thornton (1939, p. 188):

It is by no means intended to imply, that it would become the Bank of England to relieve every distress which the rashness of country banks may bring upon them: the bank, by doing this, might encourage their improvidence. There seems to be a medium at which a public bank should aim in granting aid to inferior establishments, and which it must often find very difficult to be observed. The relief should neither be so prompt and liberal as to exempt those who misconduct their business from all the natural consequences of their fault, nor so scanty and slow as deeply to involve the general interests. These interests, nevertheless, are sure to be pleaded by every distressed person whose affairs are large, however indifferent or even ruinous may be their state. 
Thorton made four key points in this passage. First, the lender of last resort's primary responsibility is to the market ("the general interests") and not to the individual bank. The central bank has no duty to sustain particular institutions. Second, the LLR must take account of the moral hazard problem. That is, it must recognize that when it makes liberal accommodation available, it may create incentives that encourage laxity and recklessness in the lending practice of individual banks. Thornton's solution to this problem was to advise against bail-out operations for banks whose distress arises from "rashness," "improvidence," or "misconduct." By subsidizing the riskbearing function of poorly managed banks, such rescue operations, he asserts, would encourage other banks to take excessive speculative risks without fear of the consequences. In short, individual imprudence should be punished by losses. Only if the financial repercussions of such punishment threaten to become widespread should the lender of last resort intervene. His third point, however, was that even in this latter case, aid should be extended sparingly and on relatively unfavorable terms. Finally, he was skeptical of the claim that economic welfare is inevitably harmed when a bank fails. This argument, he noted, would provide every large bank, no matter how poorly run, with an automatic justification for aid. He was aware that occasionally the public interest may be better served by the demise of inefficient banks, because the resulting improvements in resource allocation may outweigh any adverse spillover side effects of the failure.

The third issue addressed by Thornton was whether the lender of last resort should try to prevent shocks to the financial system. Here Thornton answered in the negative. The lender of last resort exists, he said, not to prevent shocks but to minimize their secondary repercussions. He argued that a panic could be triggered by any kind of "alarm"; for example, rumors of a foreign invasion, an initial bank failure, and so on. The central bank has no responsibility for stopping these triggering events, but it does have a responsibility for arresting the panic, stopping it from spreading throughout the system. "If any one bank fails," said Thornton (1939, p. 180), "a general run on the neighboring ones is apt to take place, which if not checked at the beginning by a pouring into the circulation a large quantity of gold, leads to very extensive mischief."

The proper response, according to Thornton, is not to stop the initial failure, but to pump liquidity into the market. In Thornton's view, the actual occurrence of a widespread panic would be properly attributable not to the initial bank failure, but to the central bank's failure to insulate the economy from the impact of that event. He 
distinguished between the effect of closing an individual bank and the policy errors of the lender of last resort. Closing an individual bank, he said, contributes very little to "general distress" or "general commercial difficulty." By contrast, policy errors of the lender of last resort create a "general shock to credit" that "produces Distress through the whole Kingdom" (Thornton, pp. 287-88, 304-5).

Finally, Thornton identified the paramount objective or primary purpose of the lender of last resort. Today, opinion varies as to the lender's ultimate objective, with all of the following being mentioned: preventing widespread bank failures; preserving confidence in the banking system; preventing a massive dumping of assets and the consequent collapse of asset values; guarding against the danger of massive currency withdrawals; and ensuring that banks and other lending institutions will be able to meet their loan commitments. Thornton, however, saw the lender of last resort's overriding objective as the prevention of panic-induced declines in the money stock, declines that could produce depressions in the level of economic activity. That is, he viewed the LLR as essentially a monetary rather than a banking function. While recognizing that the LLR also functions to forestall bank runs and avert credit crises, he insisted that these functions, although undeniably important, were nevertheless ancillary and incidental to the LLR's main task of protecting the money supply. In other words, the LLR's crisis-averting and runarresting duties were simply the means (albeit the most efficient and expeditious ones) through which it pursued its ultimate objective of preserving the quantity, and hence the purchasing power, of the money stock. The important point was to prevent sharp short-run shrinkages in the quantity of money, since hardship ensued from these rather than from bank runs or credit crises per se.

In this connection, he drew a sharp distinction between bank credit (loans and discounts) on the one hand and the stock of money on the other. He then argued that, while the two aggregates tend to rise and fall together, it is the fall of the money stock that does the damage to the real economy. More precisely, he asserted that, while credit indeed finances and supports business activity, such credit arises from money rather than vice versa. Since credit springs from money and not money from credit, it follows that monetary contractions rather than credit collapses per se are the root cause of lapses in economic activity. Regarding this point, Thornton (1939, p. 307) asserted that a run-induced contraction in bank credit is not as harmful as the corresponding decline in the money stock: "It is not the limitation of Discounts or Loans, but . . . the limitation of Bank Notes 
or of the Means of Circulation that produces the Mischiefs [of unemployment and lost output]."

To show how such monetary contractions and the resulting fall in output and employment would occur in the absence of an LLR, Thornton traced a chain of causation running from an alarm or rumor to financial panic to the demand for high-powered money to the money stock itself and thence to aggregate spending and the level of real economic activity. Panics, he noted, trigger doubts about the solvency of country banks and the safety of their note and deposit liabilities. As a result, moneyholders seek to convert these assets into money of unquestioned soundness, namely gold or Bank of England notes. These two items, he noted, comprise the base of high-powered money, an unaccommodated increase in the demand for which in a fractional reserve banking system is capable of causing a multiple contraction of the money stock. The demand for base money, he said, is doubly augmented during panics; for at the same time that moneyholders are attempting to convert suspect country bank notes and deposits into gold or its equivalent, country banks are also seeking to augment their reserve holdings of these high-powered monetary assets, not only to meet anticipated cash withdrawals but also to allay public suspicion of financial weakness. The result is a massive rise in the demand for base money-a rise that, if not satisfied by increased issues, produces sharp contractions in the money stock and equally sharp contractions in spending. Since Thornton contended that wages and prices were downwardly sticky and therefore responded sluggishly to declines in spending, it follows, he said, that output and employment will bear most of the burden of adjustment; that is, the monetary contraction will fall most heavily on real activity.

To prevent this sequence of events, the LLR must stand ready to accommodate all panic-induced increases in the demand for highpowered money. This it can readily do since it has a monopoly over its own banknote component of the monetary base. Expressed in modern terminology, Thornton's argument was essentially this: The LLR must be prepared to offset falls in the money multiplier arising from panic-induced rises in the currency and reserve ratios with compensating rises in the monetary base. By so doing, it maintains the quantity of money intact and therefore also the level of economic activity.

\section{Monetary Controversies of the Mid-19th Century and the Concept of a Lender of Last Resort}

As Charles Rist (1966, p. 383) indicated: "Henry Thornton's description [of a central bank acting as the fulcrum of the entire 


\section{Cato Journal}

English money market] is the first of its kind in English economic literature." Thornton's seminal contribution to the concept of the LLR was the most thorough discussion of this function to that date. Few refinements to his LLR views were made until the debate initiated by the Bank Charter Act. The period of restriction ended in 1821 as Britain returned to a metallic standard. During the next half century, a good deal was learned about the operation of a central bank. And it was during this period that Bank of England notes became de jure in addition to being de facto legal tender. ${ }^{6}$ By this time, the Bank of England had also become the central reserve of gold for the English banking system. That is, the Bank became the central reserve against notes as well as the central reserve against deposits (Smith 1936, pp. 15-16, 122-23).

In general, important contributions to the LLR concept were formulated after financial crises. (Indeed, Thornton was importantly influenced by the financial crises of 1793 and 1797.) Similarly, the several monetary crises in the 1821-44 period stimulated important debate and discussion related to this function. A much-discussed concern of this period, for example, was how to keep periodic severe drains of gold from causing drastic shrinkages in the note issue (Daugherty 1942, p. 141). Since England was an open economy under fixed exchange rates during the period, the objectives of the Bank of England were to maintain convertibility of the currency in the long run and to prevent credit crises from causing monetary contraction in the short run. Almost all monetary writers of the period fully endorsed this long-run objective. The only notable exception was the Birmingham School (the Attwood brothers and their disciples) and a few other proponents of inconvertible paper standards. The controversies of the period, therefore, centered around the short-run policies pursued by the Bank of England and their relation to the crises that periodically affected England. Such discussions often directly pertained to the LLR.

\section{Developments Leading $U p$ to the Bank Act of 1844}

Three important financial crises occurred between 1821 (the year Britain returned to a metallic standard) and 1844 (the year the Bank Act was passed): the crises of 1825, 1836, and 1839. Much discussion and controversy among monetary writers of the day focused on the proper role of the Bank of England during these crises. Several writers associated with both the Currency School and the Banking

${ }^{6}$ In 1833, Bank of England notes officially became legal tender. See, for example, Hawtrey (1962, p.131) and Vera Smith (1936, p.14). 
School participated in this discussion. Their differing policy proposals often had important implications for the LLR function, and it is these aspects of the period's discussion that are emphasized here.

While Henry Thornton clearly recognized and delineated the special LLR responsibilities of the Bank of England, several important monetary writers of the mid-19th century did not support his views. ${ }^{7}$ Several writers believed the Bank of England was "just like any other bank" and, consequently, should be managed no differently than any other bank. ${ }^{8}$ One important implication of this view was that the Bank of England had no special LLRR responsibilities. Levels of reserves maintained at the Bank of England did not need to be higher than those of other banks and, like other banks, the Bank should curtail lending in times of crisis (Wood 1939, p. 156). According to this view, a curtailment of lending was appropriate for any type of drain, external or internal. Supporters of this view apparently did not recognize the responsibilities inherent in a government monopoly of legal tender issuance (Hawtrey 1962, p. 131).

These views were supported by the Currency School writers, who focused on maintaining convertibility and preventing periodic severe short-run financial crises such as those experienced during this period. In their view, such crises arose because of the note-expansion policies of the Bank of England and the commercial banks. According to these writers, convertibility was not sufficient in and of itself to prevent such short-term financial crises. Even under convertibility, for example, the Bank of England and country banks could issue notes to excess (Viner 1965, p. 235). Far from gently contracting the volume of notes immediately upon the first loss of gold, banks often continued to issue notes even as gold was flowing out, delaying contraction until the last moment when reserves were nearly depleted. This contributed to violent monetary contractions that affected the entire economy and sometimes precipitated a convertibility-threatening financial crisis. In short, according to the Currency School, convertibility alone was not a sufficient safeguard of monetary stability.

To prevent these drastic monetary contractions and to assure continued convertibility, some additional mechanism was needed-specifically, control over the note issue. The proposed control mecha-

${ }^{7} \mathrm{By}$ the mid-1800s, Thornton's writings were largely forgotten, having long since fallen into oblivion. His subtle analysis had been eclipsed by the more simplistic doctrinos of Ricardo. Perhaps this is the main reason why his ideas received so little support. Even the Banking School writers who enumerated ideas very similar to his had largely forgotten him. He was rediscovered and rescued from total obscurity only in the 20th century, by J. Viner, J. Hollander, J. Angell, and F. V. Hayek.

${ }^{8}$ Sir Robert Peel, for example, endorsed this view. See Sayers (1957, p. 9), 
nism took the form of a nondiscretionary rule which rigidly connected note issuance with gold movements and gave the Bank of England a monopoly over note issue. Currency School writers believed that a mixed currency of paper and coin was properly regulated if it were made to behave exactly as gold coin; that is, automatically expanding and contracting pound for pound with inflows and outflows of gold ${ }^{9}$ This was equivalent to a 100 percent gold reserve backing for bank notes. Currency School writers believed that if the Bank of England consistently followed such a rule, overissuance of notes would be prevented and, consequently, the violent financial crises and real disturbances described above would be eliminated. ${ }^{10}$ There would be no need for discretion, since no serious economic disturbance or financial crises would occur. In other words, Currency School writers believed that there would be no need for the Bank to exercise discretion once a rule requiring notes to vary one for one with gold was in place (Fetter 1965, p. 176). Under such a rule, all drains were to be treated alike, just as they would be by any private bank, and restriction would be the rule in all cases of a loss of reserves by the Bank of England. Since no discretion was necessary, the Bank could disregard the causes of a drain. After all, to distinguish between causes of a drain would give too much discretion to the Bank's directors.

With respect to its banking (deposit taking and lending) versus its issuing function, the Bank of England should also act just like any other bank, according to Currency School writers. This view, for example, was voiced by Frank Fetter (1965, p. 258):

They [Currency School writers] had, in their insistence on the rigid regulation of note issues, either specifically or implicitly taken the view that the Bank, in its banking operations, should act just like any other bank. The logical corollary of this was that the Bank had no responsibility in time of crisis greater than the ordinary bank had to its customers and the community, that it had no need to keep a larger reserve in its Banking Department than any other bank, and that it should strive to maximize profits in the same way as other banks.

"See, for example, Daugherty (1942, p. 143), where the author indicates that Currency School writers believed that "Currency reform must be in the direction of making the existing mixed currency closer to that of a pure metallic currency. The mixed currency ought to vary quantitatively as a pure metallic currency."

${ }^{10}$ Currency School writers were not exclusively concerned with financial crises. They also were concerned with avoiding business cycles caused by monetary overexpansion and contractions. This point is forcefully made by Ludwig von Mises, who gave the Currency School eredit for being the precursor and originator of the Austrian monetary overinvestment theory of the business cycle. 
This Currency School view left little or no role for a lender of last resort to avert liquidity panics and domestic cash drains. Since no discretion was allowed, Bank action was often supposed to parallel the behavior of "any other bank," and all drains were to be treated alike with restrictive action, the Bank of England would not act as a lender of last resort. According to writers of the Currency School, their policy proposals eliminated the fundamental causes of financial panics, thereby making the lender of last resort unnecessary.

\section{The Bank Charter Act of 1844}

The Bank Charter Act of 1844 largely embodied the prescriptions of the Currency School writers:

1. The Bank of England was divided into two departments: an issue department (to issue notes in exchange for gold and to pay out gold on demand for notes) and a banking department (to receive deposits and make loans).

2. The Act limited the issue department to a maximum issue of notes uncovered by gold of $£ 14,000,000$. Issues above this amount had to be 100 percent covered by gold; that is, notes above this amount would be issued only in exchange for gold (Viner 1965, p. 220; Withers 1909 , p. 204). This in effect implied that "the bank would be unable to meet the claims of its depositors with its own notes or with specie once the reserves of the banking department had been exhausted" (Viner 1965, p. 229). Thus, it prevented the banking department from being able to use funds available in the issue department during a crisis (Fetter 1965, p. 209). This aspect of the Act constrained the Bank of England by severely limiting its ability to expand the note issue in time of crisis; that is, it effectively removed important lender-of-lastresort powers.

3. The Act placed Bank of England notes under a strict regulation which in essence made the Bank of England obliged to deal with internal and external drains in the same way. ${ }^{\prime \prime}$

4. The Act eliminated competitive note issuance by giving the Bank of England a monopoly of note issue. ${ }^{12}$

\footnotetext{
"See, for example, Elmer Wood (1939, p. 154), where he asserts that "as a result of the Act of 1844 the Bank felt obliged to restrict credit drastically even though the exchange was favorable during the October panic [of 1847]."

${ }^{12}$ See Vera Smith (1936, p. 18), where she remarks that "It was the 1844 Act which ensured the ultimate monopoly of the note issue in the hands of the Bank of England."
} 


\section{CATO JOURNAL}

Thus, the Bank Charter Act of 1844 essentially removed important LLR powers from the Bank of England and forced the Bank to respond to both internal and external drains with restrictive policies. This Act induced the Bank of England to act as if it had no important "public" responsibilities in dealing with panics and crises (Fetter 1965, p. 204). Indeed, as Smith (1936, p. 125) pointed out, one of the cardinal principles of the 1844 Act was considered to be that:

The Bank of England should be released from any obligation to pay attention to the public interest in framing its policy and should be at liberty to act for the benefit of its shareholders, the principles of management by the Banking Department being the same as those regulating any other large deposit bank.

\section{Events After 1844}

The Bank Charter Act did not eliminate financial crises as the Currency School writers believed it would. In the years after 1844, the reform measures embodied in the Act were put to severe tests by three turbulent financial crises in 1847, 1857, and 1866. All of these financial crises were characterized by sharp internal drains or panics. As indicated above, however, the Bank Act prevented the Bank from acting as an LLR. In all of these crises, the government found it necessary to temporarily suspend the Bank Act. Thus, these crises showed the government always ready, on the only occasions when it was necessary, to exempt the Bank from the provisions of the Bank Act (Smith 1936, p. 18), allowing it to issue notes uncovered by gold in excess of the statutory limits imposed in the Bank Charter Act. ${ }^{13}$ Such note expansion was considered necessary to stem the internal drain or panic. In short, the government rescinded the restriction and thereby enabled the Bank to serve as an LLR. In all three cases, either the mere suspension of the Act (as in 1847) or the expanded note issue was sufficient to stop the internal drain; that is, the provision of LLR services halted the panics.

These crises and the need for special government action to deal with them forced a reconsideration of certain provisions of the Bank Act. In particular, a deficiency of the Act appeared to be its prohibition of last-resort lending. Several Parliamentary committees recommended the incorporation of a "relaxing clause" (or an "elastic clause") into the Act. Such a clause would enable the Bank to temporarily provide LLR services in the special case of an internal drain or panic.

${ }^{13}$ In 1847 there was no actual infringemont of these limits. See Daugherty (1943, p. 242). 
A "relaxation clause" had been opposed by Currency School writers on the grounds that it would lead the public to believe that an increase in note issues would easily and promptly occur should any perceived problems arise. They also thought there was a danger that the clause would be used too soon and too often, thereby becoming the rule rather than the exception. Consequently, incentives would be created for banks to forego adopting necessary correctives and instead take more risks; that is, a moral hazard problem would arise. Banks, for example, would have an incentive to hold smaller reserves and liquid assets, thereby increasing the likelihood of financial crises (Mints 1945, p. 119). Currency School writers also believed that if the public anticipated relaxation, foreign drains would not be stopped. Finally, such a clause would allow discretion and, in addition, introduce a departure from the principles of metallic currency (Daugherty 1943, p. 243).

\section{The Banking School}

Banking School writers (such as Tooke, Fullarton, Wilson, and Gilbart) disagreed with Currency School writers on many of these issues and, indeed, opposed the Bank Act of 1844. The principal writers of the Banking School did not begin to attack Currency School theories until shortly before the Bank Charter Act was passed (Daugherty 1942, p. 148). Events after 1844, however, provided support for their views of the LLR function.

In opposing the views of the Currency School, Banking School writers insisted that the Bank of England should not behave "just like any other bank." 14 They believed that a special role existed for the Bank of England and that in the case of an internal drain, any individual commercial bank's attempt to expand would result in an immediate loss of reserves without significantly changing the overall situation. An individual bank, therefore, would be induced to contract rather than expand its operation (Smith 1936, p. 66). In the case of an internal drain, Banking School writers argued, it was essential for some nonprofit-seeking holder (or creator) of the ultimate reserve of the system to pursue an expansionary policy (Mints 1945, p. 248). No other institution would be able to inspire the same degree of confidence or have its notes accepted as readily. The bank which

\footnotetext{
"See, for example, Thomas Tooke, who stated: "A great mistake was committed by the framers of the Act of 1844, in the assumption that the Barking Department of the Bank of England admits of being conducted in the same way, and with the same effects on the interest and convenience of the Public, as any other non-issuing Joint Stock Bank," On the Bank Charter Act of 1844 (London, 1856), p. 142, reprinted in Fetter (1965, p. 261),
} 


\section{Cato Journal}

holds (or creates) the ultimate reserve has the ability to lend in a crisis and thereby has the great advantage over other institutions, which run the risk of stopping payment if their reserves are exhausted (Hawtrey 1962, p. 131). In short, Banking School writers contended that, unlike other banks, a loss of reserves should not normally result in a restriction of the issue of Bank of England notes. In their view, the Bank of England should expand its note issuance during an internal drain or panic and be a lender of last resort. By providing these services, the bank would stem the panic and might prevent the suspension of convertibility as well.

In carrying out such LLR responsibilities, there were other ways in which the Bank of England should not behave "just like any other bank." Banking School writers insisted that the Bank of England should hold larger reserves than other banks (Fetter 1965, p. 261), which would promote confidence in the Bank's ability to manage various types of drains. Larger reserves would also permit the Bank to easily manage temporary external drains without disrupting domestic circulation by serving as an "exchange defense fund" (Wood 1939, p. 155). Since Banking School writers (such as Tooke and Fullarton) believed that most foreign gold flows were caused by temporary factors, a large reserve would enable the Bank to deal with frequent temporary external drains and not affect the domestic economy (Daugherty 1942, p. 154; Mints 1945, p. 120). Finally, larger reserves would also give the Bank more ability to use discretion in its treatment of various gold drains.

Banking School writers opposed the Bank Act of 1844 for several reasons. In their view, one of its defects was that it failed to allow for different policy prescriptions in the case of alternative types of drains; the Act obliged the Bank to deal with all drains in the same waywith restrictive policies. ${ }^{15}$ Banking School writers endorsed a definite LLR role for the Bank of England, maintaining that three distinct types of drains existed and discretion was necessary so that the Bank of England could distinguish among them before applying a proper policy remedy for each. A mechanistic rule was inappropriate because of the different causes and types of these drains. Instead, proper policy prescriptions included expansion for an internal drain, contraction for a permanent external drain, and the use of its large reserve stock to manage a temporary (self-correcting) external drain. In short, according to Banking School writers (and contrary to Currency School

\footnotetext{
${ }^{15}$ Indeed, John Stuart Mill supported the Banking School writers on this issue. He indicated that "the [Bank] Act hindered the Bank from taking the steps which would give relief when a crisis had occurred." See Viner (1965, p. 234).
} 
writers), contractionary policy was inappropriate in both the cases of an internal drain and a temporary external drain. ${ }^{16}$ The view that the various types of drains should not be dealt with in the same manner, of course, was not new. Henry Thornton had stated that the Bank should deal differently with the alternative types of drains (Wood 1939 , p. 154).

As mentioned above, the Currency School's support of the Bank Act was based on the view that convertibility was not, in and of itself, sufficient to prevent financial crises. Some additional mechanism was necessary to control the note component of the domestic monetary base, and the Bank Act's nondiscretionary rule was supposed to provide that control. Banking School writers believed that in the case of the small open economy, convertibility, together with bank lending against real bills, would suffice to provide control of the domestic note component of the monetary base and thereby prevent financial crises. Modern scholars have recently demonstrated that under a convertible currency, the real bills criterion would indeed function to control the paper component of the money stock. ${ }^{17}$

The events after 1844 tended to support Banking School views on the role of the Bank of England as an LLR during an internal drain. Financial crises had encouraged various monetary writers to delineate their views on the proper role of Bank of England, and the crisis of 1866 stimulated one particularly well known monetary writer. $\mathrm{He}$ subsequently put the capstone on the 19th-century debate concerning the domestic LLR. His name was Walter Bagehot.

\section{The Contribution of Walter Bagehot}

The post-1844 case for the lender of last resort received its strongest and most influential exposition in the writings of Walter Bagehot.

\footnotetext{
${ }^{16}$ As Viner has indicated, J. S. Mill also made "distinctions between internal drains, external drains which were self-corrective in character, and external drains which could be checked only by a change in relative price levels, and criticized the Act of 1844 on the grounds that it forced the Bank to apply identical treatment to all three types of drains. [Mill] claimed that a mechanical rule for the regulation of note issue was objectionable because it would prevent different treatment of the different types of drains." See Vinor (1965, p. 262).

${ }^{17}$ See, for example, Thomas M. Humphrey (1982) and David Laidler (1983). These authors, for example, point out that the Banking School relied on convertibility to fix the price level of the small open economy and on the real bills criterion to tie the growth rate of the paper component of the money stock to the growth rate of real output. They also argue that when convertibility is absent (so that nothing exists to anchor the price level), the real bills criterion by itself offers no constraint or limitation to the price level or the quantity of money in existence. Hence the traditional Mints/monetarist criticism is correct in an inconvertible paper currency regime but is not valid if convertibility reigns.
} 


\section{Cato jounnal}

In his seminal 1873 volume, Lombard Street, Bagehot at once clarified, refined, and advanced many of the pro-LLR propositions underlying the position of the Banking School. In so doing, he revived and restated many of the points made earlier by Thornton. Following Thornton, he emphasized the Bank of England"s special position as the holder of the ultimate reserve. This position, he noted, not only rendered the central bank different from ordinary commercial banks, but also gave it the power as well as the duty to lend freely in a crisis, the very time when other bankers would be contracting their loans. He also followed Thornton in advocating that the Bank of England hold large buffer stocks of gold reserves, from which periodic drains could be met without adversely affecting the quantity of money in circulation. Finally, like Thornton, he distinguished between the appropriate response to internal versus external cash drains. An internal drain, he said, should be countered by a policy of lending freely and vigorously to erase all doubt about the availability of bank accommodation. An external drain, however, should be met by a sharp rise in the central bank's lending rate, the high interest rate serving to attract foreign gold and encouraging the retention of domestic gold. This latter action, Bagehot thought, was necessary to protect the nation's gold reserve, the gold component of the monetary base. According to Bagehot (1962, p. 155), "the first duty of the Bank of England was to protect the ultimate cash of the country, and to raise the rate of interest so as to protect it."

A sufficient gold reserve, of course, was necessary both for the preservation of the gold standard and for the maintenance of public confidence in the convertibility of paper currency into gold. Regarding public confidence, Bagehot (1962, pp. 156-57) argued that "a panic is sure to be caused" if the gold reserve falls below "a certain minimum which I will call the "apprehension minimum." "It follows that the lender of last resort should strive to keep its gold reserves above this critical threshold.

Bagehot (1962, pp. $27-28$ ) thought that a persistent external drain would trigger an internal drain as the public, observing the diminution of the gold stock and fearing a prospective suspension of cash payments, would seek to convert deposits and country bank notes into gold. "Unless you can stop the foreign export," he said, "you cannot allay the domestic alarm." In this case, in which "periods of internal panic and external demand for bullion commonly occur together," the lender of the last resort must "treat two opposite maladies at once-one requiring stringent remedies, and especially a rapid rise in the rate of interest; and the other, an alleviative treatment with large and ready loans." Therefore, "the best remedy ... 
when a foreign drain is added to a domestic drain" is the provision of "very large loans at very high rates." Here is the origin of the famous Bagehot Rule: "lend freely at a high rate."

Like Thornton, Bagehot stressed that last-resort lending should not be a continuous practice but rather a temporary emergency measure applicable only in times of banking panics. And, in perfect accord with his predecessor, Bagehot argued that if the central bank responded promptly and vigorously, the panic would be ended in a few days, by implication an interval not long enough for the domestic note component of the money stock to depart significantly from its appropriate long-1un growth track.

Bagehot also viewed the role of the leader of last resort as primarily macroeconomic. The central bank, he said, bears the responsibility of guaranteeing the liquidity of the whole economy but not that of particular institutions. Thus, he prescribed last-resort lending as a remedy solely for emergencies affecting the entire banking system, not for isolated emergency situations affecting an individual bank or a few specific banks. Nor did he intend it to be used to prevent very large or key banks from failing as a consequence of poor management and inefficiency. As shown below, he did not think that support of such distressed key banks was necessary to forestall panics. Like Thornton, he emphasized that the task of the central bank was not to prevent initial failures but rather to prevent a subsequent wave of failures spreading through the system.

Bagehot also followed Thornton in arguing that the lender of last resort exists not to prevent shocks but to minimize the secondary repercussions following them. His views on this point are contained in his analysis of panics, which, said Bagehot $(1962$, p. 61), can be triggered by a variety of exogenous events-" "a bad harvest, an apprehension of foreign invasions, a sudden failure of a great firm which everybody trusted." But "no cause is more capable of producing a panic, perhaps none is so capable, as the failure of a first-rate joint stock bank in London"(Bagehot 1962, p. 29). The shock of this initial failure must be contained before it gets out of hand, for "in wild periods of alarm, one failure makes many." The problem is how to "arrest the primary failure" that causes "the derivative failures." Bagehot's solution, quoted below (1962, p. 25), stresses the liberal provisions of liquidity to the whole system rather than loans to the distressed bank:

A panic, in a word, is a species of neuralgia, and according to the rules of science you must not starve it. The holders of the cash reserve must be ready not only to keep it for their own liabilities, but to advance it most freely for the liabilities of others. They must 


\section{Cato JournaL}

lend to merchants, to minor bankers, to 'this man and that man,' whenever the security is good. ... The way in which the panic of 1825 was stopped by advancing money has been described in so broad and graphic a way that the passage has become classical. "We lent it,' said Mr. Harmon, on behalf of the Bank of England, 'by every possible means and in modes we had never adopted before; we took in stock on security, we purchased Exchequer bills, we made advances on Exchequer bills, we not only discounted outright but we made advances on the deposit of bills of exchange to an immense amount, in short, by every possible means consistent with the safety of the bank, and we were not on some occasions overnice. Seeing the dreadful state in which the public were, we rendered every assistance in our power.' After a day or two of this treatment, the entire panic subsided, and the 'City' was quite calm.

Conspicuously absent is any mention of the need to channel aid to specific institutions, as would be implied by bail-out operations. Bagehot's emphasis is clearly on aid to the market rather than to the initially distressed bank. He obviously did not think it necessary to prevent the initial failure at all costs.

Up to this point, Bagehot has been depicted largely as a follower or disciple of Thornton. But Bagehot did more than just elaborate, refine, and coordinate Thornton's analysis. He also contributed several original points that added substance to the lender-of-last-resort doctrine and advanced it beyond Thornton's formulation. At least five of these points deserve mention.

First, Bagehot distinguished between the central bank's extending support to the market after a crisis began, and its giving assurance of support in advance of an impending crisis. He argued that the lender of last resort's duty did not stop with the actual provision of liquidity in times of crisis, but also involved making it clear in advance that it would lend freely in all future crises. As Bagehot (1962, p. 85) put it, "the public have a right to know whether [the central bank]-the holders of our ultimate bank reserve-acknowledge this duty, and are ready to perform it." This assurance alone, he thought, would dispel uncertainty about and promote confidence in the central bank's willingness to act; thus generating a pattern of stabilizing expectations that would help avert future panies.

Second, he advocated that last-resort accommodation be made at a penalty rate. Borrowers should have relief in times of crises, but they should be prepared to pay a price that implied a stiff penalty. The central bank has a duty to lend, but it should extract a high price for its loans, a price that would ration scarce liquidity to its highestvalued uses just as a high price rations any scarce commodity in a free market. Moreover, a penalty rate also had the appeal of distri- 
butional equity, it being only fair that borrowers should pay handsomely for the protection and security afforded by the lender of last resort. Allocative efficiency and distributive justice aside, the penalty rate, Bagehot claimed, would produce at least four additional beneficial results. First, it would encourage the importation and prevent the exportation of specie, thus protecting the nation's gold reserve. It would achieve this result by attracting short-term capital from abroad and by exerting a deflationary influence on the level of economic activity and domestic prices, thereby improving the external balance of trade by spurring exports and reducing imports. Second, consistent with the objective of maintaining stable growth of the note component of the money stock, a penalty rate would ensure the quick retirement of emergency expansions of the note issue once the emergency ends. The very unprofitability of borrowing at the abovemarket rate would encourage the prompt repayment of loans when the panic subsides, and the resulting loan repayment would extinguish the emergency issue so that the money stock would return to its noninflationary path. Third, the high rate of interest would reduce the quantity of precautionary cash balances that overcautious wealthholders would want to hold. Without the high rate to deter them, these cashholders might deplete the central gold reserve. As Bagehot put it, the penalty rate would serve as "a heavy fine on unreasonable timidity," prompting potential cashholders to economize on the nation's scarce gold reserve. In this connection, he advocated that the penalty rate be established "early in the panic, so that the fine may be paid early; that no one may borrow out of idle precaution without paying well for it; that the Banking reserve may be protected as far as possible" (Bagehot 1962, p. 97).

Last and most important, the penalty rate would, in addition to rationing the scarce gold reserve, provide an incentive for banks to exhaust all market sources of liquidity and even develop new sources before coming to the central bank. By encouraging individual banks to develop better techniques of money management and the capital market to develop new channels to mobilize existing liquidity, the penalty rate would promote allocative efficiency in the financial system. In short, the penalty rate would protect the gold reserve, minimize deviations of the growth of the domestic note component from its stable path, allocate resources by market price, discourage reliance on the central bank, and ensure that recourse to the latter's lending facilities was truly a last resort.

Bagehot's analysis, it should be noted, implies still another use for the penalty rate: providing a test of the soundness of distressed borrowers. A penalty rate set a couple of percentage points above the 
market rate on alternative sources of funds would encourage illiquid banks to turn to the market first. Snccess in obtaining accommodation at the market rate would indicate that lenders judge these borrowers to be sound risks, for the borrowers and their assets would pass the market test. On the other hand, resort to the central bank would tend to indicate weaknesses in the borrowing institutions, suggesting that the banks may be unable to borrow in the market at the lower rate. Fearing default, lenders may demand a risk premium in excess of the difference between the market rate and the penalty rate, forcing the banks to close, to arrange a merger with other banks, or to resort to the central bank's lending facility. Thus, the penalty rate will have provided a test of the banks' soundness.

Bagehot's third contribution was his specification of the types of borrowers the lender of last resort should accommodate, the kinds of assets it should lend on, and the criteria it should use to determine the acceptability of those assets. Regarding the types of borrowers, he stated that the Bank of England should be willing to accommodate anyone with good security. Last-resort loans, said Bagehot (1962, p. 25), should be available "to merchants, to minor bankers, to this man and that man." The objective of the central bank in time of panic is to satisfy the market's demand for liquidity. It makes little difference, he said, whether this objective is accomplished via loans to merchants, to bankers, or to whomever.

Concerning the type of collateral on which the central bank should lend, Bagehot's answer was clear. The bank should stand ready to lend on any and all sound assets, or, as he put it, "on every kind of current security, or every sort on which money is ordinarily and usually lent" (Bagehot 1962, p. 97). Besides the conventionally eligible bills and government securities, acceptable collateral should include "all good banking securities," and perhaps even "railway debenture stock" (pp. 97, 101). In another passage he makes the point that the "amount of the advance is the main consideration ... not the nature of the security on which the advance is made, always assuming the security to be good" (p. 101). The basic criterion was that the paper be indisputably good in ordinary or normal times. The latter qualification is important. It implies that the lender of last resort should not be afraid to extend loans on normally sound assets whose current market value is temporarily below book value owing to depression in the securities market.

To summarize, Bagehot felt that few restrictions should be placed on the types of assets on which the central bank might lend, or the kinds of borrowers it might accommodate. This position was consistent with his advocacy of price as opposed to non-price rationing 
mechanisms. He recommended that the central bank eschew qualitative restraints-eligibility rules, moral suasion, administrative discretion and the like-and instead rely on the penalty rate to ration borrowing.

Fourth, Bagehot provided a precise delineation of the extent of the lender of last resort's responsibility to individual banks as distinguished from the banking system as a whole. Concerning the question of whether this responsibility included assistance to insolvent banks, Bagehot's answer was an unequivocal no. The central bank's duty, he said, is not to rescue "the "unsound" people" who constitute "a feeble minority." Such businesses, he said, "are afraid even to look frightened for fear their unsoundness may be detected" (Bagehot 1962, p. 97). In short, the job of the central bank is not to prevent failure at all costs but rather to confine the impact of such failure to the unsound institutions alone.

Bagehot meant for his strictures to apply even to those key banks whose failure, in the absence of central bank action, could shatter public confidence and start a falling-dominoes sequence of financial collapse. Thus, Bagehot (1962, p. 129) acknowledged that if

\begin{abstract}
owing to the defects in its government, one even of the greater London joint stock banks failed, there would be an instant suspicion of the whole system. One terra incognita being seen to be faulty, every other terra incognita would be suspected. If the real government of these banks had for years been known, and if the subsisting banks had been known not to be ruled by the bad mode of government which had ruined the bank that had fallen, then the ruin of that bank would not be hurtful. The other banks would be seen to be exempt from the cause which had destroyed it. But at present the ruin of one of these great banks would greatly impair the credit of all. Scarcely any one knows the precise government of any ane; in no case has that government been described on authority; and the fall of one by grave misgovernment would be taken to show that the others might easily be misgoverned also. And a tardy disclosure even of an admirable constitution would not much help the surviving banks: as it was extracted by necessity, it would be received with suspicion. A skeptical world would say 'of couse they say they are all perfect now; it would not do for them to say anything else.'
\end{abstract}

Even in this case, however, Bagehot did not think it appropriate for the central bank to extend aid to poorly managed key banks. It is, instead, "the "sound' people, the people who have good security to offer" who constitute "the majority to be protected." The lender-oflast-resort function should not be interpreted to mean that unsound banks should not be permitted to fail, but it implies that failure should not be allowed to spread to sound institutions. To Bagehot, the 


\section{Cato Journal}

distinction is crucial. In his words, "no advances indeed need be made" on assets on "which the [central] Bank will ultimately lose." Again, in another passage, he offers assurance that if the lender of last resort "should refuse bad bills or bad securities" it "will not make the panic really worse." To arrest a panic, he says, it is sufficient that the bank guarantee to provide liquidity to the "solvent merchants and bankers" who comprise the "great majority" of the market. This policy ensures that "the alarm of the solvent merchants and bankers will be stayed" (Bagehot 1962, p. 97).

Finally, Bagehot warned against undue reliance on the lender of last resort and stressed the need to strengthen individual banks. The lender of last resort, he pointed out, was not meant to be a substitute for prudent bank practices. Consistent with his laissez-faire, freemarket philosophy, he argued that the basic strength of the banking system should rest not on the availability of last-resort accommodation but rather on the resources and soundness of the individual banks. According to Bagehot (1962, p. 36):

[W] e should look at the rest of our banking system, and try to reduce the demands on the Bank [of England] as much as we can. The central machinery being inevitably frail, we should carefully and as much as possible diminish the strain upon it.

Bagehot (1962, p. 60) described in glowing terms the self-reliant character of a hypothetical decentralized "natural system of banking," composed "of many banks keeping their own cash reserve, with the penalty of failure before them if they neglect it." Elsewhere he pointed out that "under a good system of banking . . . a large number of banks, each feeling that their credit was at stake in keeping a good reserve, probably would keep one; if any one did not, it would be criticized constantly, and would soon lose its standing, and in the end disappear" (Bagehot 1962, p. 52). In relying on its own soundness rather than the resources of the central bank, such a system, he noted, "reduces to a minimum the risk that is caused by the deposit. If the national money can safely be deposited in banks in any way, this is the way to make it safe" (p. 53).

One final observation should be made concerning Bagehot's views on the central bank's most appropriate instrument to combat panics. Today many banking experts regard open market operations, rather than discount window accommodation, as the most effective way to deal with systemic liquidity crises. Bagehot undoubtedly would have agreed. Although he consistently prescribed loans, rather than open market purchases of assets, to stop panics, this was only because the latter weapon was not widely used in his day. Had the technique of 
open market operations been highly developed at that time, he undoubtedly would have approved of its use, at least in those cases where there was no danger of the gold stock being depleted by a foreign drain. On these occasions, Bagehot favored resorting to the most expeditious means of stopping an internal cash drain. Open market operations are quite consistent with his dictum "that in time of panic" the central bank "must advance freely and vigorously to the public ... on all good banking securities" (Bagehot 1962, pp. 9697). Moreover, open market operations would have appealed to his preference for market-oriented allocation mechanisms. He would have approved of this particular policy instrument, which regulates the total amount of money but not its allocation among users or uses.

\section{Summary of the Domestic Lender of Last Resort}

The essentials of the domestic LLR concept found in the 19thcentury writings of Thornton, the Banking School, and Bagehot can be summarized in the following propositions:

1. The LLR's emergence depends critically on fractional reserve banking and central bank monopoly over legal tender issuance. The first condition (which renders unaccommodated emergency increases in the demand for high-powered money capable of causing multiple contractions in the money stock) provides a need for an LLR; the second (which gives the LLR sole power to create high-powered money) provides the means of satisfying that need.

2. The LLR is essentially a monetary rather than a banking or credit function. The LLR exists to prevent panic-induced contractions in the money stock, contractions that would adversely affect the level of real economic activity. True, the LLR also functions to forestall bank runs and prevent credit shocks from becoming widespread. But these functions, although undeniably important, are nevertheless ancillary to the LLR's main task of maintaining the aggregate quantity of money unchanged in the face of a panic.

3. The LLR function applies to all monetary regimes. Moreover, in accomplishing its mission, the LLR supports other central banking objectives under alternative regimes. Under a metallic (gold standard) regime, the LLR helps protect the gold reserve and thus contributes to the maintenance of convertibility by stopping panics that trigger reserve-depleting internal specie drains, by raising the discount (penalty) rate to attract gold from 
abroad, and by accommodating emergency demands for highpowered money with its own note issue, thereby rendering gold unnecessary for that purpose. Likewise, under an inconvertible paper currency regime, the LLR helps stabilize the value (purchasing power) of the monetary unit by preventing catastrophic collapses of the money stock.

4. The LLR function in no way conflicts with the monetary control function of the central bank. The latter function consists of maintaining long-run stable growth of the domestic note component of the money supply (that is, the component comprising the entire money stock under inconvertible paper regimes but only the noninternational reserve component under metallic regimes). By contrast, the LLR function refers merely to temporary and relatively minor deviations from that stable note growth path. These deviations should be small both in magnitude and duration since the LLR issues base money only to offset panic-induced rises in currency and reserve ratios leaving the money stock largely unchanged. Also decisive LLR action (and the public's expectations of the same) will stop panics within a matter of days, before the note issue gets much off track. In any event, the deviations will be self-correcting as the LLR's penalty rate, by encouraging prompt repayment of lastresort loans, ensures the quick retirement of the emergency issue, thus bringing the note component back on path. By preventing monetary instability associated with panics and crises, the LLR actually complements the monetary control function and is also consistent with the notion of gradualism (that is, the avoidance of sharp monetary shocks to real activity).

5. The LLR has a macroeconomic rather than a microeconomic responsibility. Its duty is to the entire economy and not to individual banks. In particular, its duty consists of making funds available to the market during actual panics and publicly acknowledging in advance its commitment to do so in all future panics. In so doing, it reduces public uncertainty and generates stabilizing expectations, both of which enhance its effectiveness. In no case, however, has it a duty to sustain unsound banks. Its watchwords should be "no public absorption of private losses due to faulty management," "no subsidization of risks," and "no bailouts of unwise, erroneous loan decisions." Poorly managed banks should be allowed to fail, with the LLR acting only to ensure that such failure does not adversely affect 
the money stock. Besides reducing the moral hazard problem, this prescription is fully consistent with the notion that the LLR exists not to prevent the occurrence of shocks, but rather to minimize the spillover or contagion effects propagated by shocks. In short, the LLR must clearly distinguish between preventing a monetary contraction and protecting the interests of bank owners and management. The former is a macro responsibility and the latter is not.

6. The LLR function can be accomplished either through open market operations or loans made at the penalty rate. The important point is to accommodate emergency demands for highpowered money. For this purpose either method is appropriate. Both possess the added advantage of using market rather than non-market mechanisms to allocate LLR liquidity among competing uses and users.

\section{The Possible Role for an International Lender of Last Resort}

Despite its lack of clarity in the contemporary literature, the case for the domestic LLR was clearly delineated and well established with the publication of Lombard Street in 1873. Since then, discussions of the LLR have pertained almost entirely to the domestic rather than the international economy, but recently international financial problems have elicited calls to extend the LLR function to the international realm. Indeed, several economists (Kindleberger 1978; Edwards 1980) contend that the IMF is already assuming this role and several proposals (for example, Dean and Giddy 1981) have been made to create an international LLR. Although the literature (especially the earlier literature) coherently describes the domestic LLR function, there are no such delineations of an international LLR role. Sketches of the latter role remain especially vague, with different premises, definitions, and understandings of the function creating semantic problems that further cloud the discussion. To dispel some of this confusion, it is helpful to ask: What can we learn about the possible role for an international LLR from the above discussion of the domestic LLR?

The Role of an International LLR: Lessons from the Domestic Case

As we indicated earlier, the need for a domestic LLR arises because of fractional reserve banking and governmental monopoly of legal 
tender issuance. While ancillary LLR roles relate to preventing both widespread banking collapse and a widespread call-in of loans and thereby collapse of asset prices, the fundamental role of the LLR is to ensure that disturbances (such as credit shocks) do not destabilize the money supply, protecting it from any sharp decrease.

In the international case, fractional reserve banking is still relevant. Although there is no international legal tender, common currencies and international media of exchange exist-particularly under fixed exchange rates (especially in the case of an international gold standard). ${ }^{18}$ Furthermore, many less-developed countries peg their monies to key currencies such as the dollar. Analogous to the domestic case, the fundamental role of an international LLR is to prevent sharp contractions of the world money stock. ${ }^{19}$

To function as an international LLR, an organization would have to be able to create world money; that is, to provide global liquidity in any amount on demand (Hawtrey 1962, p. 274). The world's central banks could turn to an international LLR only if such a body were the ultimate source of international reserves, because if such an international bank had to borrow funds to lend, it would not be the last resort (Dean and Giddy 1981, p. 41). Only where there is a single central reserve-holding bank will responsibility for being an LLR devolve to a single bank.

\footnotetext{
${ }^{18}$ An international medium of exchange also exists under "dirty float" systems as evidenced in recent years.

I"Some disagreements exist as to the appropriate moasurement of a world money aggrogate. Undor a world fixed exchange rate regime, world money is measured as the sum of national monies each multiplied by its fixed exchange rate with (that is, converted into) the numeraire currency. Under a floating cxchange rate regime, distgreements exist as to how (or if) a world monetary aggregate can be moasured. Whereas some economists contend that such an aggregate cannot be moasured under a floating exchange rate regime, others have used various methods to calculate a proxy for the world money supply. Some analysts have converted monies into a common currency by employing end-of-period or period average exchange rates. Sec, for cxample, Turney (1982), Others have calculated a global aggregate by measuring the growth of individual monies each weighted by gross domestic product and aggregating the result (the weights based on a benchmarked period). Sce, for oxample, Ronald McKinnon (1982) and H. Robert Heller (1976).

An international LLR does not necessarily relate to all "international liquidity" problems. International liquidity problems, for example, sometimes relato to balance of payments (or exchange rate) adjustments. Such adjustments are inherent and necessary eloments of an equilibrating adjustment process. Moreover, one country's balance of payments deficit (currency depreciation) is another's balance of payments surplus (currency appreciation). These adjustments, then, are not general, worldwide adjustments but rather pertain to particular countries. Thus, it is not clear that such events call for an international LLR.
} 
In the domestic case, when domestic bank notes are all convertible into a common legal tender currency, there is a role for an LLR since any widespread increase in the demand for the ultimate currency (legal tender) can be satisfied only by its single supplier, the LLR. An analogy to this holds in the international case under fixed exchange rates (where national currencies are convertible into a common international money or currency). For example, if the demand for an international medium of exchange increases and banks face runs from foreign depositors seeking to remove their money (in the form of an international medium of exchange) from the countries in which their deposits are located, it is possible that the respective central banks of these countries would face a run on their international reserves. If these central banks desire to maintain a fixed exchange rate, they may ultimately have to borrow from other central banks or from an international LLR (the ultimate source of international money) which can supply such an international medium of exchange. Under these particular circumstances, an international LLR may be needed. ${ }^{20}$

In the domestic case, when domestic bank notes are not convertible into a common legal tender (as in the case of a free banking system), there is no necessary role for an $L L R$ since there would be no increase in the demand for any type of bank note. Indeed, before the existence of a domestic LLR, suspensions of cash payments (or suspensions of the convertibility of deposits and bank notes into currency or gold), as well as bank holidays, sometimes therapeutically served to limit runs and, hence, to prevent sharp decreases in the domestic money stock. ${ }^{21}$ An analogy holds in the international case. If in the international case described above, central banks face a run on their international reserves and cannot attain (or borrow) the international medium of exchange, they may suspend convertibility and allow their currencies to depreciate and thereafter fluctuate freely against other currencies and the international medium of exchange. Just as in the domestic case (without a monopoly of legal tender issuance), an LLR may not be necessary in this instance. Under flexible exchange rates, an international LLR may not be as essential as a domestic

\footnotetext{
${ }^{20}$ See Hawtrey (1962, pp. 228,278 ) and Smith (1936, p. 169). See also Robert Aliber (1984, p. 26), where he suggests the following instances of the need for an international lender of last resort; a shift in investor (or central bank) demand from assets with high credit multiplicrs to those with lower credit multipliers-from dollar assets to gold or to SDR: and a shift from commercial bank liabilities in one country to central bank liabilities in another.

${ }^{21}$ Sce, for example, Smith (1936, pp. 38, 40,45, 134, and 136); and Friedman and Schwartz (1963, pp. 8, 109-10, 124, 157, 160, 163-64, 167, 328).
} 


\section{Cato Journal}

LLR with monopolized legal tender issuance (Smith 1936, p. 164, n. 1; Moggridge 1981, p. 50; Aliber 1984, p. 27).

\section{An International LLR: Historical Precedents?}

Although exact parallels cannot easily be drawn, the purpose of any international LLR would be to provide a backstop or a mechanism to prevent sharp contractions of the world money supply, preventing world shocks (such as credit crises) from developing into world monetary crises. Several economists have asserted that at certain times, international LLRs have (in effect) already existed, and others maintain that the lack of an international LLR has caused some major world financial crises.

Under the pre-1914 gold standard, for example, it is sometimes asserted that the Bank of England took responsibility for stabilizing the international monetary system (Withers 1909, pp. 212, 221, 236). The Bank of England at this time was the world's premier central bank and well understood the role of an LLR. According to Withers (1909, p. 210):

The fact that London has remained the only market in which every draft and every credit are immediately convertible into gold as a matter of course, has greatly intensified the responsibility of the Bank of England as custodian of a gold reserve, which is liable to be drawn on at any time from all quarters of the habitable globe from which a draft on London may be presented.

Such an assertion led to the belief that the Bank of England served as an international LLR. Fetter (1965, p. 255), for instance, stated in his text:

[A] widely held belief of economists-expressed more in oral tradition than in formal presentation-[was] that the successful operation of the international economy before 1914 was due to the Bank of England's action as managing director, or as executive secretary, of the international gold standard, and to the City of London's role as an international lender of last resort.

Although the Bank of England may have provided critical central bank services, it did not meet the requirements for an international LLR-the Bank was not the ultimate creator of international reserves.

The lack of an international LLR has been singled out by some economists, notably Charles Kindleberger $(1973 ; 1978)$, as the primary reason for the worldwide financial and monetary collapse of the $1930 \mathrm{~s}$. Certainly, no mechanism was available at that time to prevent the contraction of the world money stock that occurred (Mundell 1983, p. 289; Humphrey and Keleher 1982, pp. 95-100). In fact, 
the experience of this period led to proposals to create such an institution. ${ }^{22}$

Although established in 1944, the IMF was created, in part, as a response to the events of the 1930s. Some analysts contend that the IMF already acts as an international LLR since it possesses substantial unused financial resources, the power to raise additional funds, a large unpledged gold stock, and the power to issue SDRs (Dean and Giddy 1981, p. 33; Weintraub 1983, pp. 43-44). The IMF, however, was not created to be an international LLR. Indeed, various proposals for an international bank that could create international reserves were explicitly rejected by the United States and other countries at the time because of a fear that excessive international money might be created. The signers of the Bretton Woods agreements definitely wanted to "guard against the possibility of its becoming a factory of international money" (Machlup 1969, p. 340). They therefore did not give the IMF reserve-creating powers. Instead, the IMF was designed to promote world tride and assist member countries with short-term balance of payments deficits through extensions of short-term loans. But the IMF could not then, and cannot today, serve as an international LLR since it cannot create money or international reserves. The only funds it can make available are those resulting from limited contributions made and agreed upon by the member countries. Once the IMF reaches this quota, its funds are exhausted; it cannot simply create money.$^{23}$ Since the ability to create money is the critical distinguishing feature of a LLR, the IMF, lacking that feature, falls well short of being a genuine, full-fledged LLR.

The Bretton Woods system was handicapped at its outset by an inadequate supply of liquidity in the form of gold. Because of this shortage, the fact that the United States emerged from the war as the world's largest economy, and the fact that a large portion of world trade was denominated in dollars, the dollar became an international reserve and medium of exchange. During Bretton Woods, then, the world functioned on a dollar standard. Since the Federal Reserve could create such reserves and had an important impact on world

${ }^{20}$ In 1932 , for example, a report was issued by a cabinet committee in Britain recommending the development of an international institution that would be allowed to issue paper gold, to be called international certificates. (Kindleberger 1978, p. 196).

${ }^{2}$ Actually, the IMF may borrow from any source and in the currency of any member country. However, it must first obtain the consent of the government of the member country in whose currency it proposes to borrow. Thus far it has borrowed limited funds from member countries but never from the markets. Furthermore, in January 1982, the IMF's Executive Board confirmed that quotas should continue to be the main source of funds. See Group of Thirty $(1983, \mathrm{p}, 2)$. 


\section{Cato Journal}

monetary growth, the Federal Reserve may have met the criteria for a full-fledged international LLR. The dollar still serves as an international reserve currency, so some economists (see below) believe that the Federal Reserve still meets these criteria.

\section{Do We Need an International LLR?}

In assessing whether we need an international LLR, most economists would agree that some reliable mechanism for preventing sharp decreases in world reserves (or world money) should be established..$^{24}$ The question is: What should this mechanism be?

In general, there are two principal positions on this issue, each supported by various groups of economists from various schools of thought. One is that no international LLR is necessary. Some monetarist-oriented economists, for example, assert that under purely flexible exchange rates with reliable (decentralized) domestic LLRs, no international LLR is necessary. In this view, each domestic LLR has the power and ability to maintain and preserve the stability of its domestic money stock. If all domestic LLRs reliably pursue their LLR responsibilities, then sharp contractions of any aggregation of domestic monies will be prevented. ${ }^{25}$ These arrangements will be sufficient to prevent monetary contractions, so the creation of an additional international agency is unnecessary.

Ironically, advocates of free money presumably join with most monetarists on this issue. The former contend that an international LLR is not necessary for many of the same reasons that they believe domestic LLRs are not necessary. ${ }^{26}$ They endorse a decentralized multi-currency system with competition between monies-a system which was explicitly endorsed by Bagehot ${ }^{27}$-and they oppose the monopolization of the creation of world reserves. Free-money proponents also argue that although individual domestic LLRs have the monopoly of legal tender issuance within their own countries, they are forced to compete with one another in the international realm (as suggested by the literature on currency substitution). All other things

\footnotetext{
24 We are not directly addressing the closely related and important issuc of alternative monetary arrangements to provide for price stability, but are focusing only on the case for an international LLR.

${ }^{25}$ In the case of the current international debt situation, domestic LLRs can prevent any serious impacts of such debt disturbances on the domestic money stock.

${ }^{26}$ See, for example, White (1981a and 1981b); Smith (1936); and the references cited therein.

${ }^{27}$ Specifically, Bagehot indicated that if he were starting de novo, he would have preferred decentralized multiple reserve, competitive note issue arrangements rather than the "unnatural" system that existed when he wrote. But he believed attempting to create such arrangements was not politically feasible.
} 
equal, such competition (albeit among government-created banks) is beneficial since it compels central banks to impose discipline upon their monetary policies. If their monies are to be acceptable, the central banks must be expected to maintain a stable value, so the dangers of excessive monetary instability are reduced. These economists, therefore, oppose the creation of an international LLR.

Another group of economists who join with monetarists and freemoney advocates on this issue are proponents of the Public Choice School. These economists oppose the creation of an international LLR because of the dangers of further centralizing the power to make decisions. They contend that the bureaucrats who would manage such an institution would (like anyone else) pursue their own interests and service the needs of their constituents rather than the public interest. Such international agencies, once created, seem never to "die or fade away," but to continue to grow regardless of whether they serve a useful purpose. If an international LLR were allowed to create international reserves, for example, what mechanism would reliably control this institution and shape the incentives of those managing it? A super-governmental agency unconstrained in its power over creation of international reserves can be expected systematically to abuse that power. Public choice economists contend that an international LLR would likely lead to more world inflation and monetary instability, so they oppose its creation.

The case against an international LLR is supported by monetarists, who believe the set of existing decentralized domestic LLRs is sufficient to prevent sharp contraction of aggregations of the world's monies and reserves; free-money advocates, who support competition among multiple monies and who oppose the monopolization of world reserve creation; and public choice economists, who emphasize the dangers of creating centralized decision-making powers in a super-governmental bureaucracy.

Other economists, however, support the creation of an international LLR. Some of these economists, for example, contend that under existing institutional arrangements, the most reliable mechanism for preventing sharp contractions in world reserves and world monies entails the creation of an international LLR. ${ }^{28}$ In supporting this position, these economists (unlike many monetarists) have recognized that during the 1970 s the magnitude of international reserve flows actually increased, rather than decreased, under existing float-

${ }^{28}$ Historically, many proposals have been made for the creation of a world LLR or world central bank. See, for example, Machlup (1964) and references therein. 


\section{Cato JournaL,}

ing exchange rate arrangements. ${ }^{29}$ Robert Mundell (1983b, p. 290), for example, contends:

From 1952 to 1969 foreign exchange reserves, mainly dollars and sterling, rose from $\$ 16$ billion to $\$ 33$ billion, a little more than doubling over seventeen years. Then from 1969 to 1981 they rose by $\$ 272$ billion, to $\$ 305$ billion, almost a tenfold increase in only twelve years...

Thus, Mundell recognizes that under current institutional arrangements, the U.S. dollar has served and is serving as an international reserve currency. Indeed, it is possible that this role has actually increased in recent years. Whether we like it or not, we have no choice but to recognize that even under current floating rates the Federal Reserve can create world reserves and that its policy importantly affects world reserves. Consequently, the responsibilities of an international LLR currently fall on the Federal Reserve. Mundell contends that under such circumstances, it would be far better to have a formal international LLR with well-specified objectives than to have the Federal Reserve performing this role. For the other "fourfifths of the world economy does not want a world monetary system based solely on the U.S. dollar, subject to the vicissitudes of U.S. politics and arbitrary management" (Mundell 1983b, p. 287). Moreover, in this view, a system of decentralized domestic LIRs is not sufficient to reliably prevent contraction of world reserves and money. Specifically, under current arrangements, there are components of the world money stock which are outside the control of domestic LLRs. ${ }^{30}$ And the system of floating exchange rates and currency substitution leads not only to destabilizing movements in world reserves and world money, but to volatile fluctuations in exchange rates and increasing pressures for trade restrictions. Thus, given the world as it exists, it would be preferable to construct alternative institutional arrangements which would more reliably prevent sharp decreases in world money.

Accordingly, Mundell (1983b, p. 292) proposes an international LLR that would have powers to create world reserves. He contends that the issues of this international institution "should be acceptable everywhere and accorded the status of legal tender in every ... country," and should be constrained by a combination of commodity

\footnotetext{
${ }^{20}$ Monetarists implicitly contend that under a purely flexible exchange rate regime, no international component of the monetary base need exist.

${ }^{30}$ Such components, for example, consist of Eurodollars as well as changes in the value of gold reserves due to changes in the price of gold. See Mundell (1983b, pp. 287-88).
} 
(gold) convertibility and constitutional rules. ${ }^{31}$ By advocating a package of commodity convertibility plus a global LLR, Mundell extends the Thornton-Banking School-Bagehot LLR prescription to the international sphere.

\section{Some Concluding Thoughts}

The purpose of this paper was to trace the development of the LLR concept in the literature and to dispel some of the confusion surrounding it. The L.LR concept has long been shrouded in controversy, originally pertaining to the need for and functions of a domestic LLR. Indeed, these issues were central to some key policy disputes in the 19 th century and served to polarize important groups of monetary writers into competing schools. These disputes, far from being sterile, served to refine and sharpen the LLR concept, identifying it as a monetary rather than a credit or a banking function and as a protector of the money supply in times of panic.

For the most part, these classical controversies referred to national money stocks and domestic LLRs. Recently, however, many of the disagreements have been elevated to the level of the international domain, where the key question refers to the necessity for a global LLR. ${ }^{32}$ Assuming that this necessity depends on the demand for international reserves (that is, world money), and that such demand ceases to exist only in the ideal textbook case of perfectly floating exchange rates, then nations have at least three possible choices with regard to a global LLR. First, they can move to a regime of more perfectly floating exchange rates, in which the need for a world LLR vanishes. Second, they can maintain the existing system of managed floating, in which the U.S. dollar (provided its value remains relatively stable) continues to serve as the key reserve currency and the intemational LLR responsibility (if indeed it exists) rests essentially with the Federal Reserve. Third, and perhaps most radically, they can create a new supranational institution with reserve-creating powers along the lines suggested by Mundell. Whichever alternative is chosen, the important point is that there must be some mechanism for preventing sharp contractions in world and national money sup-

\footnotetext{
${ }^{31} \mathrm{~A}$ third alternative also exists in the litorature. Specifically, several proposals have been made whereby key countries (such as the United States, Japan, and Germany) closely coordinate their monetary policies with the objcctive of stabilizing the growth of an aggregate of the dollar, yen, and mark. Ronald McKinnon (1982) has made proposals along these lines. Such proposals are a sort of middle ground between a single international LLR and the docentralized domestic LL.Rs supported by most monetarists. ${ }^{32}$ Free-money advocates, of course, continue to insist on the abolishment of domestic LLRs.
} 


\section{Cato Journal}

plies. This is the central message of the LLR literature surveyed in this article. If this message is correct, then stabilizing national and world money stocks, rather than increasing IMF quotas and/or creating new credit facilities, is the appropriate policy prescription for international debt problems.

\section{References}

Aliber, Robert Z. "Bagehot, the Lender of Last Resort, and the International Financial System." Working paper, University of Chicago Graduate School of Business, 1984.

Bagehot, Walter. Lombard Street. 1873. Reprint. Homewood, Ill. Richard D. Irwin, 1962.

Barth, James R., and Keleher, Robert E. " "Financial Crises' and the Role of the Lender of Last Resort." Federal Reserve Bank of Atlanta Economic Review 69 (January 1984): 58-67.

Daugherty, Marion R. "The Currency-Banking Controversy," Pt. 1. Southern Economic Journal 9 (October 1942): 140-55.

Daugherty, Marion R. "The Currency-Banking Controversy," Pt. 2. Southern Economic Journal 9 (January 1943): 241-51.

Dean, James W., and Giddy, Ian H. Averting International Banking Crises. The Monograph Series in Finance and Economics. New York: New York University, 1981.

Edwards, Franklin. "Financial Institutions and Regulations in the 21st Cen" tury: After the Crash." New York: Columbia University, 1980. Mimeographed.

Fetter, Frank W. Development of British Monetary Orthodoxy 1797-1875. Cambridge, Mass.: Harvard University Press, 1965.

Friedman, Milton, and Schwartz, Anna J. A Monetary History of the United States 1867-1960. Princeton, N.J.: Princeton University Press, 1963.

Group of Thirty. The International Monetary Fund and the Private Markets. New York: Group of Thirty, 1983.

Hawtrey, Ralph. The Art of Central Banking. London: Frank Cass and Co., Ltd., 1962.

Heller, H. Robert. "International Reserves and World-Wide Inflation." International Monetary Fund Staff Papers 23 (March 1976): 61-87.

Humphrey, Thomas M. "The Classical Concept of the Lender of Last Resort." Federal Reserve Bank of Richmond Economic Review 61 (January/February 1975): pp. $2-9$.

Humphrey, Thomas M. "The Real Bills Doctrine." Federal Reserve Bank of Richmond Economic Review 68 (September/October 1982): 3-13.

Humphrey, Thomas $\mathbf{M}_{1}$, and Keleher, Robert E. The Monetary Approach to the Balance of Payments, Exchange Rates, and World Inflation. New York: Praeger Publications, 1982.

Kindleberger, Charles P. The World in Depression, 1929-1939. Berkeley: University of California Press, 1973.

Kindleberger, Charles P. Manias, Panios, and Crashes, New York: Basic Books, 1978. 
Laidler, David. "Adam Smith as a Monetary Economist." Canadian Journal of Economics 14 (May 1981): 185-200.

Laidler, David. "Misconceptions About the Real Bills Doctrine and the Quantity Theory: A Comment on Sargent and Wallace." Research Report No. 8314. University of Western Ontario, May 1983.

Machlup, Fritz. "The Cloakroom Rule of International Reserves: Reserve Creation and Resources Transfer." In International Finance, Edited by R. N. Cooper. Baltimore: Penguin Books, 1969.

Machlup, Fritz. Plans for Reform of the International Monetary System. Special Papers in International Economics No. 3, revised ed. Princeton, N.J.: International Finance Section, Princeton University, March 1964.

McKinnon, Ronald I. "Currency Substitution and Instability in the World Dollar Standard." American Economic Review 72 (June 1982): 320-33.

Mints, Lloyd W. A History of Banking Theory. Chicago: University of Chicago Press, 1945.

Moggridge, D. E. "Financial Crises and Lenders of Last Resort: Policy in the Crises of 1920 and 1929." Journal of European History 10 (Spring 1981): 47-69.

Mundell, Robert A. "International Monetary Options." Paper presented at the Cato Institute conference on "The Search for Stable Money," Washington, D.C., January 21-22, 1983a. [Subsequently published in the Cato Journal 3 (Spring 1983): 189-210.]

Mundell, Robert A. "International Monetary Reform: The Optimal Mix in Big Countries." In Macroeconomics, Prices, and Quantities: Essays in Memory of Arthur Okun. Edited by James Tobin. Washington, D.C.: Brookings Institution, $1983 \mathrm{~b}$.

Rist, Charles. History of Monetary and Credit Theory. New York: Augustus M. Kelley, 1966.

Sayers, Richard S. Central Banking After Bagehot. Oxford: Clarendon Press, 1957.

Smith, Vera. The Rationale of Central Banking, London: P. S. King and Son Ltd, 1936.

Thornton, Henry. An Enquiry Into the Nature and Effects of the Paper Credit of Great Britain. 1802. Edited with an Introduction by F. A. von Hayek. New York: Rinehart and Co., 1939.

Timberlake, Richard $\mathrm{H}$. The Origins of Central Banking in the United States, Cambridge, Mass.: Harvard University Press, 1978.

Turney, James C. "Essays in International Economics." Ph.D. dissertation, University of Southern California, 1982.

Viner, Jacob. Studies in the Theory of International Trade. New York: Augustus M. Kelley, 1965.

Weintraub, Robert E. International Debt: Crises and Challenge. Washington, D.C.: Department of Economics, George Mason University, April 1983.

White, Lawrence H. "The Free Banking Question in the British Monetary Controversies, 1800-1845." Paper presented at American Economic Association Meeting, Washington, D.C., December 1981a. 


\section{Cato Journal}

White, Lawrence H. "Theoretical Issues in the Free Banking Controversy." Working paper, Department of Economics, New York University, December $1981 b$.

Withers, Hartley, The Meaning of Money. London: Smith, Elder and Co, 1909.

Wood, Elmer. English Theories of Central Banking Control 1819-1858. Cambridge, Mass.: Harvard University Press, 1939. 


\section{THE LENDER OF LAST RESORT AND A MONEY SUPPLY RULE

\author{
David I. Meiselman
}

The Humphrey-Keleher paper provides an interesting and illuminating survey of some of the important literature in the history of economic doctrine and in monetary theory. ${ }^{1}$ I have little to quarrel with or to add to their historical analysis. Instead, my comments are related to the fact that I believe the paper is incomplete when the authors shift their attention to the current scene. My comments are primarily directed to suggesting some updating of their excellent analysis.

Most of the discussion of the lender of last resort (LLR) concept has been rather vague since Bagehot, as the Humphrey-Keleher paper indicates. The role of an LLR has been framed primarily in terms of worse case, scare scenarios. It would be useful to subject the LLR concept to a rigorous and systematic analysis, including, for example, the appropriate goals, targets, and indicators for an LLR. Such an analysis would produce a body of tested knowledge about what to do (and what not to do) before a crisis.

The term "lender of last resort" may itself be a source of much mischief and confusion. One reason is that the term confounds money and credit, and similarly confounds the problems of credit markets and those resulting from sharp changes in the quantity of money, especially a monetary collapse. The Humphrey-Keleher analysis points this out very clearly, and I have nothing to add to their analysis on this issue.

Cato Journal, Vol, 4, No. 1 (Spring/Summer 1984). Copyright O Cato Institute. All rights reserved.

The author is Professor of Economics and Director of the Graduate Economics Program in Northern Virginia, Virginia Polytechnic Institute and State University, Falls Church, Va.

'Thomas M. Humphrey and Robort E, Keleher, "The Lender of Last Resort: A Historical Perspective," Cato Journal 4 (Spring/Summer 1984): 275-318. 


\section{Cato JOURnal}

It is useful to evaluate alternative monetary regimes, as the authors have done to some degree, and in the process, to examine the stabilization properties of alternative regimes, even under various "scare" scenarios. For example, consider a regime characterized by fractional reserve banking and a money supply rule that fixes the growth rate of money. Assuming a financial panic, can there really be a "liquidity" crisis?2 In my judgment, it would be most unlikely, perhaps close to impossible.

If the monetary authority abides by the money supply rule, it is hard to see any role for an LLR. Under a money supply rule, it seems to me that we would have a situation similar to the one that Bagehot described, where the monetary authority would make "funds" freely available to maintain the desired money stock. This would be the credit aspect of not permitting the money supply to collapse when there is an increase in the currency-deposit ratio or the reservedeposit ratio which, for a given stock of reserves, would lower the money multiplier and contract the money supply. Alternatively, with a monetary base rule, some deviation from a base target may be desirable when there are significant changes in the currency-deposit ratio or in the reserve-deposit ratio, as may occur during a panic.

Most of the discussion of a money supply rule has emphasized its desirable price and output stabilization properties. Perhaps we should also add the desirable credit stabilization or LLR qualities to a money supply rule, as well.

With respect to institutions and phenomena peculiar to the United States, $I$ am especially curious about the role and connection between the Federal Deposit Insurance Corporation (FDIC) and the LLR function of the monetary authority, especially given the unique role of the FDIC in the U.S. banking system. I believe this merits extensive and serious treatment.

Although $I$ appreciate the interesting and useful survey of the history of doctrine regarding the LLR, I believe it would help the discussion if we considered the question: What would have happened in the past decade if the Federal Reserve had engaged in no micro bailouts, and instead, had tried to maintain whatever money stock was indicated by their own targets? For example, what if, under Arthur Burns, the Fed had not taken special steps to bail out Franklin National Bank, or, under Paul Volcker's chairmanship, what would have happened if the Fed had achieved its money targets but there

"The term "liquidity" remains quite vague, and I continue to search for a good, workable definition. 
had been no central bank intervention in the silver crisis, or when the Mexican debt problem surfaced in August 1982?

Incidentally, I take issue with the notion advanced in some quarters that the turn in monetary policy in mid-1982 can be attributed to the Fed's response to the Mexican debt problem. The Mexican debt problem came to a head in late August 1982, which was after interest rates had fallen sharply and after the Federal Reserve had changed monetary policy in June 1982, when it shifted from an overly tight monetary policy (with essentially no money growth for six months) to an overly easy monetary policy (with $\mathrm{Ml}$ growing at 15 percent per annum). Thus, even if the Fed had intervened to help Mexico or Mexico's bankers, or if the Fed were to intervene to supply credit to an improvident foreign government, $I$ do not see the connection between that step-whether merited or not-and the necessity to move from zero money growth to a 15 percent growth path for $\mathrm{M}$ l.

I believe the alternative explanation of Fed monetary behavior in mid-1982 was that the economy was in very poor condition, that the forecast for economic recovery had not been realized, and that the Fed, and especially the administration, panicked in the face of upcoming congressional elections.

Finally, the Humphrey-Keleher paper discusses Robert Mundell's recent proposal for an international LLR with powers to create world reserves. This proposal is simply another request for still another printing press, run by still another group of international bureaucrats, with the result being still another engine of inflation. We and other countries have more than enough problems with our own central banks without adding another. However weak the constraints happen to be on the central banks of individual countries, these constraints are even weaker when international civil servants are in charge. 